\title{
D. Dinis e o processo de pacificação com o clero: o estabelecimento das concordatas no reino português
}

\author{
D. Dinis and the process of pacification with the clergy: the establishments \\ of the concordat the portuguese kingdom
}

\begin{abstract}
Láisson Menezes Luiz ${ }^{1}$
1 Doutorando em História pela Universidade Federal de Goiás, sob a orientação da professora Dra. Adriana VIdotte. Bolsista CAPES/FAPEG. Email: laissonmenezes@gmail.com.

Recebido em 26 de março de 2021; Aceito em 29 de junho de 2021.
\end{abstract}

DOI: $10.12957 /$ nearco.2021.58666

\section{Resumo}

Quando o monarca português D. Dinis (1279-1325) assumiu o trono, encontrou um reino em crise devido às discordias dos monarcas anteriores com o poder eclesiástico. Os problemas com o clero foram pacificados com o estabelecimento das Concordatas em 1289. Portanto, depois de vários anos de conflitos, D. Dinis foi o monarca que, conseguiu atenuar as relações entre o a coroa e o clero.

Palavras-chave: D. Dinis, Clero, Concordatas.

\begin{abstract}
When the portuguese monarch D. Dinis (1279-1325) take on the throne, he found a kingdom in crisis due to the discord the monarchs as ecclesiastical powers. The problems with a clergy have been resolved by the formation of the Concordats in 1289 . Therefore, after several years of conflict, D. Dinis was or monarch to obtain attenuate the relationship betwenn the crown and the clergy.
\end{abstract}

Key-words: D. Dinis, Clergy, Concordats.

D. Dinis foi o sexto monarca português, governou por longos 46 anos de 1279 até 1325, e uma de suas preocupações foi resolver os conflitos existentes entre a coroa e o clero, que se arrastavam desde o reinado de D. Sancho I (1185-1211) e foram agravandose nos reinados de D. Afonso II (1211-1223), D. Sancho II (1223-1248) e D. Afonso III (1248-1279). No início de seu reinado, D. Dinis teve que enfrentar uma crise entre a igreja e a coroa, uma vez que o reino português estava sob o interdito papal, o que causou grandes transtornos à sociedade, pois as igrejas estavam fechadas e os cultos 
suspensos, e desde o final do reinado do seu pais, D. Afonso III, parte dos bispos portugueses encontravam-se em Roma. Somente após um longo período, as negociações chegaram a um bom termo, resultando na promulgação das concordatas.

Neste sentido, buscaremos neste artigo analisar as duas concordatas estabelecidas, entre o monarca português D. Dinis e o clero no ano de 1289, que segundo António Domingues de Sousa Costa (1966, p. 29), ocupam um “[...] lugar de proeminência nos tratadistas do Direito Concordatário, onde se apresentam como tipo característico de concordatas [...]". Entre os assuntos abordados por esse documento, destacamos o desrespeito aos privilégios, liberdades e bens eclesiásticos, além de queixas relativas ao lançamento de um interdito ou excomunhão pelo clero, isenção do foro eclesiástico e abusos cometidos contra o patrimônio das igrejas portuguesas. Há ainda reclamações contra às Inquirições anteriormente lançadas, contra a cobrança indevida de impostos, como a terça para a manutenção de muralhas, bem como contra as limitações impostas pelo monarca aos escambos feitos entre instituições religiosas.

Sobre a definição de concordata, geralmente é o nome designado para as convenções realizatas entre as autoridades eclesiásticas e civil, sobre determinados assuntos controversos, de interesses para ambas as partes, com aceitação de certos deveres e reconhecimentos dos direitos da Igreja por parte do Estado e concessão de privilégios da parte da Igreja (COSTA, 1975, p. 143). Essa prática não foi exclusiva do reinado de $D$. Dinis, os monarcas anteriores também chegaram a realizar dizersos acordos com o clero, como a que foi celebrada entre D. Sancho I e D. Martinho Rodrigues, bispo do Porto, confirmada por Inocêncio III em 13 de maio de 1210. Houve também acordos semelhantes ralizadas durante os reinados de D. Afonso II e D. Sancho II, onde o assunto era sempre o mesmo, violação dos privilégios e imunidades eclesiásticas, ingerência do monarca em assuntos de ordem espiritual, infração de regalias dadas ao clero (COSTA, 1966, p. 31-32). Portanto, os acordos celebrados entre os procuradores do papa e dos do rei, são designadas de concordata (CAETANO, 2000, p. 350).

O período que estamos estudando vai da segunda metade do século XIII até a primeira metade do século XIV e foi caracterizado pela supremacia do papa na Europa 
cristã. Qualquer atitude de príncipes ou reis que fosse contra os preceitos da Igreja era duramente reprimida, com deposições de monarcas, lançamentos de interditos sobre uma região ou um reino inteiro, além de excomunhões, entre outras penas.

No caso do reino português, o clero:

[...] que além de agir sobre um povo devoto, estava sempre pronto, quando não obtivesse da parte do rei satisfação às suas pretensões, para transferir as queixas para o plano da Santa Sé que, para mais, era suserana do monarca português em virtude da vassalagem prestada por D. Afonso Henriques (CAETANO, 1992, p. 288-289).

Dessa forma, um fator intrigante no reinado de D. Dinis é justamente sua relação com o poder eclesiástico. Esse monarca, diferentemente de seus antecessores, apesar de exercer uma política de centralização do poder régio, tendo como princípio acabar com a influência do clero sobre a sociedade portuguesa, e mexendo principalmente nas propriedades eclesiásticas e em seus privilégios, não sofreu nenhuma pena eclesiástica mais dura. De fato, isso contraria o que aconteceu, por exemplo, com seu avô, D. Afonso II, que morreu excomungado, com seu tio, D. Sancho II, que foi deposto do trono pelo papa e com seu pai, D. Afonso III, que mesmo sendo colocado no trono pelo clero, como delegado do papa e ter jurado obediência à Igreja, morreu excomungado, apesar de ter se retratado com os religiosos pouco antes de sua morte. Essa é uma das inquietações que pretendemos compreender a partir da análise das concordatas estabelecidas durante o reinado de D. Dinis.

\section{O processo de negociação das concordatas entre D. Dinis e o clero português}

Em relação à situação entre a coroa e o poder eclesiástico, a negociação levou cerca de dez anos. Assim que assumiu o trono em 1279, D. Dinis empenhou-se na conciliação com o clero. Naquele ano, pontificava Nicolau III (1277-1280), vindo a falecer no ano seguinte, em 1280. Demorou seis meses até que um novo papa fosse escolhido, sendo na ocasião, Martinho IV (1281-1285). Durante esse período, D. Dinis reuniu-se na cidade da Guarda com os prelados, freires das ordens militares, barões e cavaleiros, na 
qual foram lidos os artigos da bula de Gregório X, expedida ainda no reinado de D. Afonso III. Essa reunião demorou certa de três semanas. O resultado foi a elaboração de um documento enviado ao papa em que os prelados relataram a boa vontade de $D$. Dinis em resolver os litígios que se arrastavam desde o reinado de seu pai e, como prova, citam o envio de procuradores à Roma que, devido à morte do papa anterior, não obtiveram sucesso.

Além disso, o próprio monarca enviou uma carta205 escrita em 23 de abril de 1282, na cidade da Guarda, ao papa Martinho IV, na qual mostrou-se interessado em chegar a uma solução para os conflitos que há muito tempo privavam as pessoas do reino português dos sacramentos da Igreja (COSTA, 1990, p. 289).

No mesmo ano, os prelados do reino enviaram uma carta à Martinho IV pedindo que confirmasse os artigos, para que a situação do reino fosse resolvida. D. Dinis, também em 1282, enviou outra carta pedindo ao papa que outorgasse a composição que ele fizera com o arcebispo e os bispos do reino. Quando Martinho IV recebeu o documento elaborado na cidade da Guarda, em 13 de novembro de 1281, pediu que fossem feitas algumas emendas nos artigos, pois considerou as respostas de D. Dinis insuficientes. Por meio da bula Ex parte venerabilium, de 25 de março de 1284, nomeou o bispo de Leão, o deão de Salamanca e o arcediago de Ledesma para entregar o texto e comunicar ao monarca e aos pelados portugueses.

As emendas feitas pelo papa estão nas bulas Isti sunt articuli, de 1 de abril de 1284 e Hec est forma, de 15 de maio de 1284. Nessas bulas, o papa exigiu que o monarca colocasse suas respostas ao fim de cada artigo e que respondesse àqueles que ainda não tinham obtido o compromisso régio, acordados com os prelados, para serem aceitos pela Santa Sé. Ao que parece, D. Dinis não respondeu todas as queixas do clero, por isso o papa considerou as respostas dadas pelo monarca insuficientes.

Porém, o papa Martinho IV faleceu antes de chegarem a um acordo, deixando a questão pendente. Para ocupar o lugar do pontífice, Honório IV (1285-1287) foi eleito

205 Esta carta foi transcrita por: ALMEIDA, Balbina Rodrigues de. D. Dinis. Breve estudo de sua chancelaria. Livro I, fls. 25-86v. 1969. (Licenciatura em História). Faculdade de Letras, UC, Coimbra. 
em 2 de abril de 1285. Em uma carta enviada ao novo Papa, escrita por Frei Telo, arcebispo de Braga, por D. Ayméric, bispo de Coimbra, por D. João Martins, bispo da Guarda e por D. Vicente, bispo do Porto, os prelados expuseram a situação em que se encontrava o reino e o processo de negociação feito com o papa anterior que, em razão de sua morte, havia sido interrompido.

Depois de receber as cópias das emendas, D. Dinis reuniu as Cortes em 1285 na cidade de Lisboa. Entre os presentes estavam barões, nobres, religiosos das ordens militares e conselheiros. Ao que parece, nessa Corte não estavam presentes Frei Telo, arcebispo-primaz de Braga, D. Ayméric, bispo de Coimbra, D. João Martins, bispo da Guarda, e D. Vicente, bispo do Porto, por estarem em Roma. Os artigos foram lidos com as respectivas emendas feitas pelo papa perante os que estavam presentes e que aconselharam D. Dinis a aceitar as emendas. Então, o monarca enviou seus procuradores Martinho Pires, chantre de Évora e Estevão Lourenço para tratarem da negociação com o papa Honório IV, que nomeou uma comissão composta por três cardeais para tratarem desses assuntos. Mas, antes de chegarem a um acordo, o papa morre, em 3 de abril de 1287, fazendo com que a negociação se estagnasse (COSTA, 1990, p. 299). Somente após nove meses um novo papa foi eleito, em 15 de fevereiro de 1288, o franciscano Nicolau IV (1288-1292).

Assim que o novo papa foi eleito, o monarca, juntamente com os prelados do reino, tratou de retomar a negociação. E foi justamente no pontificado de Nicolau IV que a situação chegou a um termo. Estavam em Roma durante esse período, o arcebispo de Braga e os bispos de Coimbra, Silves e Lamego. Como juízes, Nicolau IV escolheu três cardeais, dois dos quais já haviam sido escolhidos por Honório IV. Os prelados portugueses e a comissão nomeada pelo papa reuniram-se na basílica de Santa Maria Maior, em Roma.

Os procuradores régios responderam artigo por artigo, em um total de 40 . Em seguida, os bispos disseram estar de acordo e satisfeitos com as respostas e promessas do monarca e, finalmente, haviam chegado a um acordo quanto aos termos da concordata. As respostas foram consideradas satisfatórias pelos juízes e, assim, o rei D. Dinis e seus futuros sucessores deveriam guardá-las e cumpri-las. Depois disso, Nicolau 
IV aprovou a concordata pela bula Occurrit nostrae consideratinis, que posteriormente foi enviada à D. Dinis pela bula Cum olim inter, de 7 de março de 1289 (PIZARRO, 2008, p. 133). Alguns assuntos que ficaram em dúvida foram tratados no mesmo ano em outra concordata, contendo 11 artigos. Nessa concordata, não houve a confirmação de nenhuma bula, mas $\mathrm{D}$. Dinis aceitou os artigos, como podemos observar em algumas cartas206 que foram enviadas pelo monarca aos bispos da Guarda, Porto, Lamego, Braga, Viseu, Coimbra e Lisboa sobre a composição dos artigos.

Portanto, o rei foi absolvido de todas as penas, o interdito foi retirado, desde que no espaço de quatro meses aceitasse a concordata, o que aconteceu nas Cortes que se reuniram em Lisboa, no dia 4 de agosto de 1289, onde o monarca firmou o compromisso de nunca mais hostilizar a Sé Apostólica, o que em partes não cumpriu. Prova disso, foi que 20 anos depois, em 1309, houve a promulgação de mais uma concordata com 22 artigos, dessa vez pleiteada apenas por D. João Martins de Soalhães (1294-1312), bispo de Lisboa, e pelo seu cabido, na qual D. Dinis era cobrado do que ele havia prometido em 1289.

\section{A concordata de 40 artigos}

Passemos, então, à análise dos artigos das concordatas, discutiremos alguns assuntos que evidenciam as relações entre o poder monárquico e o poder eclesiástico em Portugal durante o reinado de D. Dinis. Para facilitar a análise dos artigos da primeira concordata, foi feita uma divisão por assuntos. Assim, os 40 artigos podem ser separados em cinco partes. Na primeira parte, do artigo I ao XII, os assuntos são referentes aos privilégios do foro eclesiástico (exercício da jurisdição), da possibilidade de excomunhão e de interdição de determinados lugares e Igrejas, e da autonomia dos clérigos na administração dos edifícios religiosos (MATOS, 2013, p. 399).

No artigo I, a queixa é com relação ao direito de padroado, um dos temas em que mais estão confundidas as jurisdições temporais e espirituais. Segundo Cassiano Malacarne (2008, p. 408), isso ocorria pois era “[...] grande demais a interferência dos

206 Ver as cartas em: CHANCELARIA de D. Dinis. Livro II. Organização: Rosa Marreiros. Coimbra: Palimage, 2012, p. 195-203. 
indivíduos laicos na organização financeira e administrativa dos templos". Esse fato se dava, pois, quem detinha tal direito, tinha o poder de nomear alguém para ocupar cargos eclesiásticos, como aponta António Manuel Hespanha (1982, p. 145-146),

O padroado era, originalmente, o conjunto de direitos que competiam ao fundador ou dotador laico de uma igreja ou mosteiro, dos quais se destacava o de participar nas rendas da instituição e o de nomear ("apresentar") o seu diretor espiritual (cura, abade, bispo). Nos tempos da reconquista coube, nomeadamente, aos reis a nomeação dos bispos, faculdade que lhes é posteriormente retirada. ${ }^{207}$

A questão da nomeação era algo que causava deveras preocupação por parte do clero, como consta no artigo III, pois "se os Bispos, ou os outros citam ou querem citar Abbades abadessas Priores ou outras pessoas, das eygreias per letras do papa, o dauandicto. Rey nom o leyxa fazer" (Livro das Leis e Posturas, 1971, p. 343)208. A resposta dos procuradores Martim Pires e João Martins de Soalhães é a mesma para ambos os artigos, isto é, o rei D. Dinis não fez isso até aqui e promete não fazer tal coisa daqui em diante, o que podemos supor que seja uma queixa relativa à D. Afonso III.

Outro assunto recorrente é sobre a possibilidade de excomunhão e de interdição de determinados lugares e Igrejas e sobre a questão da execução da jurisdição eclesiástica, presente nos artigos II, IV, V, VI e VII. Como consta no artigo II,

se os bispos, ou os Priores das eygreias scomungam seus freiguesses porque Ihis nom dam sas dizimas, ou os outros dereitos que lhis deuem ou põem. entrediçom. en seus logares assy como a Justiça manda. Elrey e os seus per caiom desto que assy scomungam faze os deytar da terra e filha lies os beens (LLP, 1971, p. 342-343).

O que observamos aqui é que o monarca não admitia que a Igreja ficasse legislando sem a sua permissão e, por esse fato, reprimia as suas ações, como podemos verificar no artigo $\mathrm{V}$, quando o

207 Essa citação encontra-se na nota 239, da referida obra do autor. 208 Utilizaremos a seguinte sigla, LLP - Livro das Leis e Posturas. 
[...] arcebispo ou bispo ou os seus vigairos põem antrediçom. em alg u logar ou em alg a eygreia. ou os homens desse Rey scomungam assy como a Justiça demanda. elRey e os seus constrangem os Bispos ou os seus vigários per ameaças ou per spantos e filhan lies seus bens pera revogarem as sentenças que derom [...]" (LLP, 1971, p. 343).

Os procuradores do monarca para essas acusações, além de dizer que o rei não fez e não fará tais coisas, prometem que quem dessa terra fizer o contrário, além de ter que reparar os danos feitos aos religiosos, também será punido.

Os artigos VIII, IX, X, XI e XII dizem respeito à autonomia dos clérigos na administração dos edifícios religiosos. No artigo VIII, os eclesiásticos reclamavam que o rei não deixava os bispos traçarem os limites de suas Igrejas e bispados. Aqui notamos a preocupação do poder eclesiástico em garantir seus domínios. Porém, o interessante é a resposta dos procuradores sobre esse assunto, na qual mostram como deve ser feito o procedimento para a limitação das propriedades eclesiásticas. Segundos os procuradores, a limitação deveria ser feita na presença do proprietário da terra, e também deveria ser publicada na Igreja em que se pretendia limitar durante três domingos consecutivos, diante do povo que estivesse presente na missa. Contudo, caso a limitação da propriedade tivesse sido feita de outra maneira, esta não teria validade. Além disso, os padroeiros que fossem ricos-homens, cavaleiros ou filhos de cavaleiros que não pudessem comparecer pessoalmente poderiam enviar seus procuradores.

No artigo $X$, segundo os eclesiásticos, o rei “[...] toma os spitãaes e as albergarias que forom ffectas pera os pobres e som so a Jurisdiçom dos Bispos de dereito e ffilha as com ssas possisões e com ssas pertenças [...]" (LLP, 1971, p. 345). Mas, o artigo não menciona quais os hospitais e albergarias que são tomados pelo rei. Como resposta, os procuradores dizem que se guarde sobre isso o Direito Comum e os bons costumes.209

209 Assim, a relação entre esses ordenamentos, segundo Rafael Sánchez Domingo (2002, p. 99) “[...] se manifesta más bien como una concordantia, de manera equivalente a como en la concepción imperial de la misma época había encontrado definición la relación entre la jurisdicción universal del Imperio y la jurisdición particular de los reinos y los comunes, los municipios, antíteses entre uno y los outros que se había resuelto em uma necesaria y oportuna colaboracíon de todos en interés de la humanidad". 
Logo, na concordata de 1289 , respectivamente nos artigos X e XXIX, quando o monarca ou o clero mencionam o direito comum, não estão se referindo a um direito particular, local ou nacional, mas sim, a um direito que abrangia toda a cristandade, uma vez que este diz respeito tanto ao direito civil quanto ao canônico. Também podemos observar nas Ordenações Afonsinas (1998, p. 12) que “[...] a Corte d'ElRey he chamado em Direito terra cõmua a todos naturaes deste Reyno, affi como a corte de Roma a todos os Chrisftaõs do Mundo".

Já os artigos IX, XI e XII, questionam as exigências do rei acerca da reforma dos muros das cidades, pois, além de confiscar parte da renda das Igrejas e bispados, o rei exigia que estes contribuíssem com materiais para construção e reforma desses muros, e também que liberassem os camponeses que trabalhavam em suas propriedades para trabalhar em tais obras, causando prejuízos aos eclesiásticos (LLP, 1971, p. 345-346). Mesmo o rei afirmando que as acusações não eram verdadeiras e que ele não procedia dessa forma, essas reclamações representavam a preocupação da Igreja em não acumular mais prejuízos, causados desde a época de D. Afonso III.

No entanto, a situação não foi resolvida, como podemos verificar em uma carta expedida pelo monarca em 22 de fevereiro de 1293, na qual D. Dinis ordena que o Concelho de Coimbra entregue aos homens de Santa Cruz de Coimbra

\footnotetext{
“[...] todalas cousas que Ihes téedes filhadas per rrazom das Pontes e das calçadas e dos Muros de que dizedes que os omes do dicto Moesteyro deuem a pagar conuosco. e leixade os star pãz. E se uos alguu direito entededes a auer contra o Priol e Conuente do dicto Mosteyro. demandade os perante a mjm. E eu ouyr ey com eles. e darey a cada huu seu direito" (GOMES, 1988, p. 92).
}

A segunda parte estabelecida aqui é constituída pelo artigo XIII, que diz respeito ao direito de asilo aos mouros, judeus e cristãos que se refugiassem nas Igrejas para escaparem da justiça régia. Os procuradores respondem que não serão retirados das Igrejas aqueles que se refugiarem nela, nem prenderão ou tomarão o que comer, exceto naqueles casos em que forem de direito (LLP, 1971, p. 346). 
A questão do direito de asilo era antiga, desde as constituições dos imperadores romanos cristãos. No caso de Portugal, o direito de asilo era garantido desde os primeiros tempos da monarquia. Como no foral de Seia de 1136, ficando estabelecido que aquele que se refugiasse na Igreja não poderia ser perseguido, mas apenas vigiado de fora. Posteriormente, isso foi alterado, conforme aponta Fortunato de Almeida (1967, p. 164). Nos foros da Guarda, o ladrão ou traidor não gozava de imunidades dentro da Igreja, mas outro que nela se refugiasse não poderia ser tirado de dentro dela, pois quem o fizesse teria que pagar trezentos soldos e restituir o preso à Igreja. 0 refugiado poderia ser vigiado de fora até o terceiro dia, mas depois, seria posto em liberdade, exceto no caso em que fosse fiador ou devedor.

No caso de D. Dinis, há uma lei de 1286 promulgada antes das concordatas, na qual o monarca manda,

[...] a todolos Alcaydes, Meirinhos, Comendadores, Juizes, Alvazys, Alcades, Justiças, e Concelhos do meu Reyno, sahude. Mando-vos, que nam prendades nenhum Clerigo por couza que faça, salvo se acaecer que faça cousa, por que meresca morte, ou penh em seus corpos, filhadeos, e dados logo a seu Bispo, ou a seus Vigarios, e lhes faram em eles ssa justiça. Item vos mando, que sse sse alguém colher alguma Egreja, por cousa que faça, ou por cyta que ay, que nom tiredes ende, neno filhedes hy, salvo outros se ffezer cousa, per que meresca morte, ou justiça em seu corpo. Unde al nom façades, se nom a vos me tornaria eu poren. Dada em Santarem, XIX dias de Dezembro, Elrrey o mandou: Aires Martins a fez, Era M. CCC. XX. IIII [...] (RIBEIRO, 1813, p. 165166).

Na referida lei, o monarca afirma que aqueles que procurem a Igreja como refúgio não devem ser tirados de dentro dela, a não ser naqueles casos em que tenham praticado crime passível de morte ou outra pena corporal. Ainda sobre o direito de asilo nas Igrejas, encontramos no Livro das Leis e Posturas (1971, p. 483) uma declaração que expõe casos em que valia o direito de asilo segundo o direito romano e o canônico. Embora não seja uma lei, intuímos que essa declaração foi utilizada para esclarecer assuntos acerca do direito de asilo até meados do século XIV. Segunda tal declaração, não teriam o direito de asilo os "[...] judeus ou mouros que deuem djujda a christãaos", ou aquele "Judeo ou mouro que faz qualquer crime". 
Na terceira parte, que vai do artigo XIV ao XIX, procura-se harmonizar a jurisdição régia e a eclesiástica por meio da afirmação do exercício do poder judicial e de mecanismos de reação aos abusos dos oficiais régios. As acusações desses artigos assemelham-se, prevalecendo aqueles sobre os abusos cometidos pelos oficiais do rei contra os eclesiásticos, como podemos observar nos artigos XIV, XV, XVI, XVII e XIX. Em tais artigos, os eclesiásticos acusavam os funcionários do rei de agirem de forma indevida e que os ovençais, alcaides, meirinhos e ricos-homens, com a ajuda de judeus e mouros, prendiam os clérigos e não os entregavam ao seu bispo, ameaçando de morte o arcebispo e os bispos e, em certos casos, matando aqueles que os seguiam. Eles ainda desonravam com palavras e ações os religiosos, clérigos e confessos, "[...] e aas vezes fazem algus deles desnuar dantes y de todo o que trazem vestido com grande doesto deles, e de toda a ordem dos Creligos" (LLP, 1971, p. 347).

Os eclesiásticos também acusaram os homens do rei, afirmando que eles tomavam as doações recebidas pelas Igrejas e ameaçavam os religiosos. Como resposta a essas queixas, os procuradores do monarca, além de dizer que este não praticou tais atos e que aqueles que os cometessem novamente seriam punidos de acordo com a justiça, também disseram que essas coisas não foram feitas no seu tempo, ou seja, foram praticadas no reinado de D. Afonso III e que ainda não tinham sido resolvidas.

A questão das violências praticadas contra os clérigos por parte de funcionários régios foi uma das reclamações mais presentes nas concordatas. Tal fato deu-se em decorrência do exagero desses funcionários ao exercerem suas funções, sobretudo, no reinado de D. Afonso III. No caso de D. Dinis, podemos perceber isso nas leis promulgadas pelo monarca, tendo seus funcionários que aplicá-las sob pena de multas e prisões. E para aqueles funcionários que não aplicassem a justiça em seus julgados, D. Dinis promulgou uma lei que dizia: “[...] aquel per que Justiça mjngar eu Ihj darey aquela mesma pea que deuiam auer aqueles que Justiça merecem nos uossos corpos, em que a uos façades" (LLP, 1971, p. 168). De fato, caso um funcionário régio não cumprisse a função que the foi confiada, como a aplicação de uma pena a um criminoso, era ele que sofreria a pena. Talvez por esse fato observamos na documentação tantos casos de abuso de poder praticados por tais funcionários. A situação agravou-se quando o 
monarca teve que intervir, instituindo um corpo de corregedores para controlar seus funcionários (MALACARNE, 2008, p. 188-189).

No artigo XVIII, os eclesiásticos reclamavam das Inquirições que, segundo eles, eram feitas de forma incorreta, pois tiravam-Ihes vários direitos e privilégios (LLP, 1971, p. 348). As acusações de desmandos do monarca continuavam com a intenção de garantir o poder da Igreja e seus privilégios. O rei negava tais acusações e comprometiase a não permitir que a situação persistisse.

As primeiras Inquirições de que se tem informação no reino português foram efetuadas no século XIII, durante o reinado de D. Afonso II, voltando a ocorrer nos reinados de D. Afonso III e D. Dinis, e prologando-se pelos reinados seguintes. Essas medidas provocaram a irritação do clero português, pois eram investigações ordenadas pelo poder central e sua aplicação procurava reprimir abusos cometidos pelos senhores laicos e eclesiásticos, e até por vilãos. "Tudo leva a crer que essas correções acabavam sendo entendidas pelo clero como confisco de propriedades eclesiásticas e, assim, consideradas como infração ao direito canônico" (MALACARNE, 2008, p. 101).

As Inquirições realizadas pelo monarca D. Dinis ocorreram entre os anos de 1284, em parte da Beira e entre Douro e Minho, e de 1288, no Minho, Trás-os-Montes e Beira. Como os abusos não cessaram, o monarca ordenou novas Inquirições em 1301 em quase todo o Minho e parte da Beira, dois anos depois, em 1303, ordenou no Minho e Trás-osMontes e, por fim, em 1307, novamente em Trás-os-Montes e na Beira. De fato, o rei não abriu mão das Inquirições, uma vez que as queixas continuaram a ser recorrentes nas próximas concordatas. Provavelmente isso ocorreu porque as medidas tomadas por D. Dinis não tiveram o efeito esperado, ou seja, continuava havendo aquisições das terras de forma indevida, o que levou o monarca a decretar novas Inquirições (MAURÍCIO, 1997, p. 20-21).

A quarta parte, que compreende os artigos XX ao XXVIII, trata dos procedimentos de efetivação do direito de padroado, sendo evidente a vontade do rei em manter a interferência de leigos na organização financeira e administrativa dos templos e, sobretudo, em perpetuar o controle da nomeação de sacerdotes. 
Nos artigos XX, XXII e XXVIII volta a questão do padroado, em que os eclesiásticos acusavam o rei de colocar como padroeiro nas Igrejas vagas pessoas de sua casa e, quando os eclesiásticos não aceitavam, os oficiais do rei ameaçavam os clérigos que não atendiam a vontade do monarca. Inicialmente, um padroeiro tinha apenas o direito de apresentação de clérigos e fiscalização da situação econômica da Igreja. Mas com o passar do tempo, passou-se a aceitar que a família do padroeiro usufruísse de parte das rendas eclesiásticas. Em meados do século XIII e, principalmente, no século XIV, apenas os pontífices passaram a aprovar os bispos eleitos depois dos padroeiros, e não mais o monarca. No entanto, o rei não deixou de interferir na nomeação de eclesiásticos, como podemos observar no artigo XXVIII da concordata, no qual os clérigos queixam-se,210 no qual notamos que o monarca enviava cartas aos cabidos das Igrejas para que fossem escolhidos religiosos de seu agrado. Como resposta, os procuradores reconheceram o erro do monarca em ameaçar os cabidos, quando o certo seria solicitar aos cabidos sem ameaçá-los.

Já nos artigos XXIV, XXV e XXVI, a reclamação dos clérigos foi em relação à interferência de laicos na organização financeira e administrativa dos templos eclesiásticos, como podemos verificar no artigo XXVI.211

Por fim, a quinta parte, do artigo XXIX ao XL, em que a discussão gira em torno de testamentos, de bens patrimoniais do clero e a isenção de serviços públicos destes e de seus dependentes. No artigo XXIX, a reclamação do poder eclesiástico era sobre a questão da herança deixada por clérigos mortos. Além de acusarem o rei de reter esses herdamentos, diziam que, se as pessoas possuíam algum bem, era graças à Igreja, dessa

210 [...] se alg as eigreias cathedraaes vagam esse Rey entendendo ganhar per ssy moor outoridade em elas anuya ssas cartas aos Cabidos da eigreias geralmente ao cabido e specialmente a ca hu Coonigo rogando os por seus clerigos da ssa Casa / ou por outros meos dignos porque espera que em nos das eygreias e nos ordinhamentos dos preytos segam ssa uootade dele $E$ essas eygreias nom deffenderam contra ele os seus dereitos nem en ssas liuridoes Estas letras enuya ele de Rogo per ameaças e per grandes spantos eu lhys pom que nom ellegam por bispo senom aquel que thes el nomear en ssas cartas ou faz nomear en ssas messageens. E aquesto mesmo ffaz em nas outras eygreias meores a que deuem de proueer do prelado ou de Reytor per enliçom. (LLP, 1971, p. 352).

211 se alg a Jgreia fez cambho conuinhauel dalg as possissões com outra eygreia per outoridade de seu bispo faz cambho com outros elRey por embargar, solamente a prol das eygreias apom embargo muyto e meudo por sse nom fazer (LLP, 1971, p. 352). 
forma, era direito da Igreja herdar esses bens. O rei comprometeu-se em respeitar o Direito Comum (LLP, 1971, p. 353).

Do artigo XXX ao XXXV, são discutidas as questões relativas às propriedades eclesiásticas. Os clérigos acusavam o monarca de cobiça aos bens da Igreja e de tomar para si as rendas das Igrejas de Braga, Coimbra, Viseu e Lamego. Destacamos o artigo XXXIII, em que a queixa era sobre o filho de D. Dinis, o futuro D. Afonso IV, que ao tornarse senhor e herdeiro dos castelos de Marvão, Portalegre e do bispado da Guarda, estava causando prejuízos a este bispado com o consentimento do rei (LLP, 1971, p. 353-356).

Nos artigos XXXVI e XXXVII, o rei foi acusado de impedir a Igreja de cobrar a dízima de mouros e judeus. Os procuradores de D. Dinis disseram que ele não cometera tais acusações e não embargara o pagamento de dízimas. E, caso houvesse alguma escritura feita durante o reinado de seu pai que diga o contrário, ele iria revogá-la.

Nos três artigos restantes, XXXVIII, XXXIX e XL, a discussão foi sobre a liberdade da Igreja. Destacamos o artigo XXXVIII, em que os eclesiásticos acusaram o monarca de

[...] quebrantamento da liuridõe da eygreia a qual certamente quebrantar quebrantar a gram fortaleza em na qual sta a ffe catholica e em na qual alteza do Rey esta endereçada. Demays astente do filhamento das cousas, sanctas a cuio deffendimento o apertador e dador de todolos Rex nos cingente despada temporal pera ffazer dereyto de ssy astente dos tortos e das perseguções / das pessoas das quaaes o encomendamento de deus deu pera honrra do seu nome. stabelecendo as pelo poboo seu e nom somente astranhastes mays constrenge os teus soietos que se astanham destas cousas. (LLP, 1971, p. 356-357).

De fato, aqui o rei foi lembrado de que seu poder foi concedido por Deus e que era de sua competência cuidar de todas as pessoas que faziam parte de seu reino, e não as maltratar. Dessa forma, o rei e todos os seus súditos deveriam honrar o nome de Deus que estava acima de todos. Como resposta, os procuradores régios disseram que o monarca não agiu contra a liberdade e nem contra os direitos da Igreja.

\section{A concordata de 11 artigos}


Ainda em 1289, outra concordata foi aprovada entre o monarca D. Dinis e os eclesiásticos portugueses, que foram feitos separadamente, pois

[...] eram caros e sobre estes nom foy posta pena e ouuerom os bipos que presentes forom / pera fazerem aueença na Corte poder do papa, pera poderem compoer sobre todolos artigos en nome seu e de todolos outros prelados que presentes nom eram (LLP, 1971, p. 363).

Tais artigos foram feitos separadamente, pois não tiveram uma resposta do monarca, donde podemos deduzir que ele não concordava com as queixas registradas pelo clero, por esse motivo, esses artigos não foram incluídos juntamente com os outros quarenta artigos. Além de não concordar com alguns artigos, o monarca também reclamou das duras sentenças que o ameaçavam caso não cumprisse o que ficara estabelecido. Esses artigos revelam muito mais as intransigências de D. Dinis que na primeira concordata de 40 artigos. Dessa forma, observamos que Nicolau IV, em certos aspectos, teve que ceder aos desmandos do monarca, "não foi uma imposição de D. Dinis - como fez Felipe IV da França - mas também não foi algo que não tenha sido feito sem a pressão política sobre Roma - através do maltrato de seus ministros - causando prejuízo à igreja" (MALACARNE, 2008, p. 109).

Em seu artigo I, foi discutida a questão referente às dízimas que o rei não queria pagar, fazendo a comunidade voltar-se contra as Igrejas e seus bispos. Sobre essa acusação respondeu Martim Pires e Johan Martins, que eram os representantes do rei, defendendo-o e dizendo que o rei deu e dará suas dízimas de pão, vinho e linho e de outras coisas e, adiante, dizem que a comunidade fizesse o mesmo, caso não fizesse, que os bispos usassem de sua justiça (LLP, 1971, p. 364).

O artigo II dizia respeito às possessões que eram compradas pela Igreja e pelos bispos atuais, bem como por seus antecessores, quando já era estabelecido que nenhuma casa religiosa comprasse propriedades sem o consentimento do rei, pois isso estava causando danos ao reino (LLP, 1971, p. 364-365). D. Dinis retoma uma lei de seu avô, D. Afonso II, nas Cortes de Coimbra de 1211, estabelecendo que mosteiros e demais ordens do reino não poderiam comprar tantas propriedades territoriais, a fim de que 
não viessem causar danos ao rei e ao reino, dando origem a demandas. Isso acabaria em dano para a Igreja e em prejuízo para o reino, por isso limitou a aquisição de possessões territoriais por parte das ordens religiosas, mas permitiu aos clérigos, individualmente, aquisição e gestão de possessões.

O artigo III tratava de reclamações dos prelados sobre os procedimentos das inquirições que estavam causando grandes transtornos aos abades, priores, reitores das Igrejas e outras pessoas religiosas. Como resposta, os procuradores disseram que, de acordo com o rei, as inquirições continuariam, segundo a forma do direito, chamadas as partes para serem ouvidas e que se corrijam as coisas que forem achadas para corrigir (LLP, 1971, p. 365). Novamente, o clero reclama das inquirições 212 realizadas pelo monarca, a saber, as terras eclesiásticas que o rei incorporava para si, dizendo que não pertenciam à Igreja. As inquirições realizadas por D. Dinis tinham como objetivo controlar os abusos senhoriais e da nobreza, mas principalmente do clero, que possuía grande quantidade de terras.

No artigo IV, o clero denunciava que eram tomados dos religiosos, pão, vinho, servos, mouros, cavalos, entre outras coisas preciosas, e que o rei, ricos-homens, alcaides, conselheiros e familiares do rei também tomavam os bens dos eclesiásticos, como vacas, porcos, carneiros, galinhas e várias outras coisas de comer e, quando geralmente recebiam de volta, era em quantidade inferior. Os procuradores falaram que o rei prometeu entregar os bens saqueados por seus homens aos clérigos (LLP, 1971, p. 366). Sobre esse assunto, D. Dinis já havia promulgado uma lei em 21 de maio de 1283, na qual o monarca mandava cavaleiros e escudeiros, entre outros homens, que filhavam pão do Celerio de Cigães, pertencente ao Mosteiro de Santa Cruz de Coimbra, deixar de fazer tais saques (GOMES, 1988, p. 79.)

$\mathrm{O}$ artigo $\mathrm{V}$ aborda a questão dos tesouros achados pelas mulheres religiosas $\mathrm{e}$ abadessas, uma vez que o rei mandava prendê-las, não respeitando sua religião nem sua dignidade, constrangendo-as contra o direito, mesmo que o tesouro achado estivesse

212 D. Dinis promoveu diversas inquirições no reino português que ocorreram nos anos de 1284, 1288, 1301, 1303-1304 e 1307-1311, fato que demonstra sua determinação em controlar os abusos cometidos pelo clero e pela nobreza. 
em sua propriedade. Em resposta a essa queixa, os procuradores régios disseram que, segundo o costume, todo tesouro encontrado no reino pertenceria à coroa. Todavia, para evitar possíveis conflitos, ficou estabelecido que, se alguém achasse tesouro em sua terra, ficasse com duas partes e a coroa com a terceira. Mas, se porventura, aquele que achar o tesouro não cumprir com as exigências estabelecidas, perderá tudo o que encontrou (LLP, 1971, p. 366-367).

No artigo VI, a reclamação era contra o pagamento de portagem, pois os eclesiásticos eram impelidos a pagá-lo à coroa caso deixassem o reino para estudos ou quando estivessem em Roma, ou em outros lugares, e levassem consigo seus haveres para sua manutenção ou para aquisição ou pagamento de dívidas. Segundo o clero, tal cobrança ia de encontro à liberdade da Igreja. A isso, os procuradores do rei responderam que o

[...] ouro ou prata ou moeda qualquer, que nom seiam portugesses que os tirem os prelados e os clérigos do reyno. ssem todo embargo de portagem. $E$ prometem que esse Rey. leyxara assy fazer des aquj adeante e que assy o aguardara. E os prelados consentem em esto por amor de paz. e de concordia (LLP, 1971, p. 367-368).

O artigo VII era referente às posses doadas por cavaleiros, mulheres fidalgas, dentre outros, para os mosteiros ou alguma Igreja em seu testamento mesmo estando vivos, pois, ainda que essas posses pertencessem à Igreja, o rei tomava-as para si. Os procuradores régios responderam que se guarde o costume do reino.

Dois anos depois, em 1291, o monarca português elaborou leis para acabar com tal situação, as quais ficaram conhecidas como "Leis de Desamortização" ou "Leis Contra a Amortização". Essas leis foram promulgadas devido às várias reclamações da nobreza com relação ao clero, pois seus parentes falecidos deixavam todos seus bens para as ordens eclesiásticas a que pertenciam, com o intuito de salvar suas almas. Faziam doações para remir seus pecados, tornando-se mais frequentes quando viam a morte aproximar-se. Dentre os principais bens doados, estavam as terras, fonte de riqueza e 
poder, e com essa concentração de terras nas mãos da Igreja, observava-se o exercício de uma política senhorial por parte das instituições eclesiásticas.

Em razão desse fato, o patrimônio das famílias estava diminuindo, o que também prejudicava o rei no que tange à defesa do reino, pois quem prestava o serviço militar eram as pessoas pertencentes à média e pequena nobreza, as quais estavam empobrecendo. No que se refere às leis, ficou decidido que os herdeiros poderiam vender um terço de seus herdamentos, porém não poderiam ser vendidos para pessoas pertencentes ao clero, como frades e freis das ordens mendicantes e "donasdordem", isto é, religiosas, e o restante ficaria com seus herdeiros. Assim, em 21 de março de 1291, D. Dinis ordenava para os encarregados de fazer cumprir a justiça no reino.

O artigo VIII referia-se aos cavaleiros e ricos-homens que, contra a vontade dos eclesiásticos, pousavam e folgavam nas casas de bispos, cônegos, nas Igrejas e catedrais, onerando os clérigos. A esse respeito, os procuradores régios responderam que o rei defendeu e defenderá que os ricos-homens e os outros de sua casa não pousem nas casas de bispos, cônegos ou de outros clérigos. E, se porventura, nas casas dos ditos bispos, cônegos e clérigos alguns, contra a vontade deles pousarem, ele os fará deitar fora, e se algum estatuto sobre isso for feito pelos clérigos ele o guardará.

Entretanto, parece que essa condição não foi respeitada, pois continuou ocorrendo casos de abusos por parte de cavaleiros e ricos-homens. Tal fato pode ser verificado em uma carta de 12 de junho de 1306, na qual D. Dinis pede ao seu meirinho de Aquém Douro, Estevão Rodrigues, que impeça os cavaleiros Martim Redondo e Martim Fernandes de Cambra de pousarem nas aldeias de Santa Marinha e de Paças da Beira, pertencentes ao Mosteiro de Santa Cruz de Coimbra, bem como Vasco Lourenço nos casais de Celorico de Beira e Vasco Peres Cerveira em Segiães (GOMES, 1988, p. 106). Em 1317, D. Dinis expediu outra carta, dessa vez enviada à Gomes Martins, meirinho-mor entre Doutro e Minho, em razão de ricos-homens, infanções e cavaleiros estarem cometendo abusos contra o Mosteiro de São Simão da Junqueira. Segundo o documento, 
[...] pousava nos logares do dicto Monsteiro e Ihj filham o que hj acham como nom deuem eles e os seus homees e que Ihi param as bestas ao Alcaçer nos sseus herdamentos e casaes do dicto Monsteiro e lhis estragam quanto hj teem e esto nom he bem se assi e. (GOMES, 1988, p. 124).

No artigo IX foram discutidos os julgamentos de eclesiásticos pelos juízes da coroa e não por clérigos e, caso apelassem para o papa, eram considerados rebeldes pelo rei, tendo seus bens confiscados. Os procuradores responderam que os clérigos fossem julgados em tribunais eclesiásticos, em assuntos pertinentes à Igreja, porém, no que tange às suas possessões, deveriam responder aos juízes seculares (LLP, 1971, p. 369).

O penúltimo artigo trazia novamente a questão referente às novas portagens impostas pelo rei aos clérigos e leigos, de maneira que deveriam cobrar de vassalos e lavradores a décima parte daqui que eles tirassem do reino. Em resposta, os procuradores do rei disseram que, segundo o costume, os reis poderiam por direito estabelecer portagem em seus reinos e nos lugares que achassem pertinentes. Todavia, o rei demanda dízima somente daquelas coisas que passam pelo mar, dessa forma, o rei não estava causando nenhum dano à clerezia, pois tais portagens eram postas com razão, conforme o direito e o costume, portanto os prelados deveriam receber isso por amor e paz. Assim, prevalecia os impostos reais (LLP, 1971, p. 369-370).

No último artigo, os eclesiásticos diziam que o rei, ao impor leis e costumes novos, prejudicava os lavradores das terras de clérigos, das Igrejas e dos leigos. Porém, nesse artigo surge uma dúvida: se a reclamação era com relação à julgada, imposto que era cobrado sobre o direito do julgo de bois. Em resposta, os procuradores régios disseram que a esse artigo o rei guardará seu foro e que o são de carta (LLP, 1971, p. 370).

\section{Considerações finais}

A partir da análise das concordatas, compreendemos as principais divergências envolvendo a coroa, o clero e a nobreza, as quais ocorriam no reino português desde o reinado de D. Afonso II. No entanto, além dos assuntos tratados no documento, vários 
outros aspectos chamaram nossa atenção, principalmente na concordata de 40 artigos de 1289, na qual os artigos não se referem apenas aos agravos cometidos durante o reinado de $D$. Dinis, mas também de monarcas anteriores. Além disso, outro dado interessante foi o processo de construção desse documento, o qual não foi exclusividade do reinado dionisino. Em nosso entender, o documento passou por um longo processo de construção, pois o clero começou a elaborá-lo em 1275, durante o reinado de D. Afonso III, quando o papa Gregório X publicou a bula De Regno Portugaliae, em que o pontífice fez uma síntese dos problemas enfrentados pela Igreja no reino português desde reinado de D. Afonso II até aquele ano. Assim, essa bula serviu de base para a construção da concordata de 40 artigos.

De fato, as concordatas de 1289 não puseram fim aos conflitos envolvendo D. Dinis e os eclesiásticos, mas não deixou de ser um marco fundamental nas relações entre a coroa e o clero no medievo português. Prova disso foi o fato de os monarcas posteriores, como D. Pedro I (1357-1367) e D. João I (1383-1433), terem sido cobrados do que D. Dinis havia prometido em 1289 (PEIXOTO, 1979, 308-338).

D. Dinis realizou um grande esforço de conciliação com o clero, observamos a diplomacia sendo empregada por este monarca para resolver suas questões. Nesse sentido, ao mesmo tempo em que o rei acabou com alguns privilégios e abusos por parte do clero, também aceitou algumas condições impostas pelo poder eclesiástico. Isso permitiu a aproximação entre o monarca e os prelados do reino, o que foi de suma importância para o poder régio construir uma gestão mais favorável, mesmo quando os eclesiásticos retomavam antigas questões, como ocorreu com D. Egas, com D. Estevão e D. Fernando Ramires.

Portanto, podemos observar que D. Dinis foi o monarca que de fato conseguiu resultados mais efetivos nas relações da coroa com o clero. Deixando para seu filho, D. Afonso IV, um reino em progresso e desenvolvimento, tanto com relação à consolidação da política de soberania régia quanto a uma dinâmica evolutiva social e econômica. 


\section{Referências}

\section{Documentação}

BULA Cum olim inter. In: LANGLOIS, M. Ernest. Les registres de Nicolas IV: recueil des bulles de ce pape. Paris: Ernest Thorin Éditeur, 1886, p. 150-158.

BULA Ex parte venerabilium. In: Les registres de Martin IV (1281-1285): recueil des bulles de ce pape. Paris: Albert Fontemoing Éditeur, 1901, p. 239-240.

BULA Hec est forma. In: Les registres de Martin IV (1281-1285): recueil des bulles de ce pape. Paris: Albert Fontemoing Éditeur, 1901, p. 240-241.

BULA Isti sunt. In: Les registres de Martin IV (1281-1285): recueil des bulles de ce pape. Paris: Albert Fontemoing Éditeur, 1901, p. 231-239.

BULA Occurrit nostrae consideratinis. In: LANGLOIS, M. Ernest. Les registres de Nicolas IV: recueil des bulles de ce pape. Paris: Ernest Thorin Éditeur, 1886, p. 158-161.

GOMES, Saul António. Documentos medievais de Santa Cruz de Coimbra. I - Arquivo Nacional da Torre do Tombo. Porto: Centro de Estudos Humanísticos da Secretaria de Estado da Cultura, 1988.

LIVRO das leis e posturas. Lisboa: Faculdade de Direito da Universidade de Lisboa, 1971.

ORDENAÇÕES Afonsinas. Livro II, Lisboa: Fundação Calouste Gulbenkian, 1998.

PRIMEIRA concordata entre D. Dinis e o clero (1289). In: ALMEIDA, Fortunato de. História da Igreja em Portugal. Volume IV. Nova edição preparada e dirigida por Damião Peres. Porto: Portucalense; Civilização. 1971, p. 61-69.

SEGUNDA concordata entre D. Dinis e o clero. In: ALMEIDA, Fortunato de. História da Igreja em Portugal. Volume IV. Nova edição preparada e dirigida por Damião Peres. Porto: Portucalense; Civilização. 1971, p. 70-73.

\section{Bibliografia}

ALMEIDA, Fortunato de. História de Portugal. Volume I. Porto: Portugalenses Editora, 1967.

CAETANO, Marcelo. Consolidação do Estado (1248-1495). In: História do Direito português (1140-1495). 3ạ edição. Lisboa: VERBO, 1992, p. 273-331. 
VERBO, 2000.

História do Direito português (Sécs. XII-XVI). 4ạ edição. Lisboa/São Paulo:

COSTA, António Domingues de Sousa. As concordatas portuguesas. Itinerarium, ano XII, no 51, p. 24-46, 1966.

Concordata. In: SERRÃO, Joel (Dir.) Dicionário de História de Portugal. Volume II. Mirandela: Iniciativas Editoriais, 1975, p. 143-145.

D. Frei Telo, arcebispo-primaz, e as concordatas de D. Dinis. In: IX centenário da Dedicação da Sé de Braga. Congresso Internacional. Actas. Volume II/1. Braga, 1990, p. 283-316.

DOMINGO, Rafael Sánchez. El derecho común. In: El derecho común en Castilla. Burgos: 2002, p. 91-108.

HESPANHA, António Manuel. História das instituições: épocas medieval e moderna. Coimbra: Livraria Almedina, 1982.

MALACARNE, Cassiano. A prática do direito adversário: as infrações institucionais de $D$. Dinis às leis canônicas (1279-1325). 2008. 535 f. (Mestrado em História). Instituto de Filosofia e Ciências Humanas, UFRGS, Porto Alegre. 2008.

MARREIROS, Maria Rosa Ferreira. A administração pública em Portugal no reinado de $D$. Dinis através do estudo de alguns documentos da sua chancelaria (Livro III, fls. 63-81v). 1973. (Licenciatura em História). Faculdade de Letras, UC, Coimbra. 1973.

MATOS, Francisco da Cunha. A concordata celebrada entre Portugal e a santa sé no reinado de D. Dinis e a estabelecida em 2004. Revista Portuguesa de História, vol. 44, p. 391-411, 2013.

MAURíCIO, Maria Fernanda. Entre Douro e Tâmega e as inquirições afonsinas e dionisinas. Lisboa: Edições Colibri, 1997.

PEIXOTO, Eduardo Melo. Derecho concordatário medieval português: de D. Dinis a D. Juan I. Revista Española de Derecho Canónico. Salamanca, v. 35, n. 101, p. 308-338, 1979.

PIZARRO, José Augusto de Sotto Mayor. D. Dinis. Lisboa: Temas e Debates, 2008.

RIBEIRO, João Pedro. Dissertações Chronológicas e Críticas sobre a História e Jurisprudência Ecclesiástica e Civil de Portugal. Apendices de Documentos. Tomo III, parte. II. Lisboa: Academia Real de Sciencias, 1813. 